\title{
MEDICINE AND THE LAW \\ Partial relief from the regulatory vacuum involving human tissues through enactment of chapter 8 of the National Health Act and regulations thereto
}

\author{
Michael S Pepper \\ Human tissue legislation is complex. An exhaustive understanding \\ of the law, thorough understanding of human tissue biology and \\ pathophysiology and an appreciation of the diversity of the areas \\ covered in this field, is critical. The importance of interdisciplinary \\ co-operation in the drafting, interpretation and implementation \\ of legislation in this area cannot be overemphasised. Several \\ factors underscore this, including the complexity and volume of \\ the information involved, rapid advances in science, reciprocal \\ dependence of the law and science on one another for relevance \\ and accuracy, and above all the need to ensure that the patient's \\ well-being and safety are not compromised. The development of \\ technology also must be encouraged in a non-obstructive legislative \\ setting. \\ S Afr Med J 2012;102(9):736-737. DOI:10.7196/SAMJ.5940
}

\section{Human tissue legislation in South Africa}

Concerning human tissue legislation, the law has traditionally struggled to match the pace of scientific and technological advances. ${ }^{1}$ In this respect, the National Health $\mathrm{Act}^{2}$ (NHA) assented to by the President on 18 July 2004 came into force on 2 May 2005. At that time matters pertaining to human tissues were legislated under the Human Tissue $\mathrm{Act}^{3}$ (HTA), since chapter 8 of the NHA, 'Control of use of blood, blood products, tissue and gametes in humans', had not been enacted. At least seven identifiable areas are covered by chapter 8 of the NHA: blood and blood products; assisted reproductive technology; cell-based therapy; transplantation; DNA and genetic services; tissue banks; and examination, allocation and disposal of human bodies and tissues.

Although chapter 8 of the NHA and the HTA that preceded it deal specifically with human tissues, ${ }^{4}$ legislation pertaining to human tissues is also governed by (without being limited to) the Medicines and Related Substances Control Act ${ }^{5}$ (Medicines Act), the Children's Act, ${ }^{6}$ the Inquest Act $^{7}$ and the Consumer Protection Act. ${ }^{8}$

\section{The regulatory vacuum: cell-based therapy, a case in point}

As identified previously, 'the HTA was drafted at a time when many of the cutting edge scientific and medical practices, which have become part of routine medical practice today, were still in their infancy or barely envisaged. This includes for example much of assisted reproductive technology, cell-based therapy and tissue banks. Many of the advances in blood transfusion, transplantation

Michael Pepper is a Professor in the Department of Immunology, Faculty of Health Sciences, and Director of the Institute for Cellular and Molecular Medicine at the University of Pretoria. He is also Professeur Associé in the Department of Genetic Medicine and Development, Faculty of Medicine at the University of Geneva, Switzerland. and genetic services which occurred subsequent to that time were likewise not provided for in the HTA.'

The previous suggestion that chapter 8 of the NHA is the major part of the legislation in South Africa that deals with the issue of cellbased therapy ${ }^{10}$ was predicated upon the recognition that this field involves several diverse but interrelated entities. This includes but is not limited to reproductive and therapeutic cloning, embryonic stem cells, tissue (and specifically stem cell) banks, tissue/organ trafficking, and the notion of profit (or lack thereof) when dealing with human tissues. It has been suggested that the Medicines Act 'is the primary legislation that regulates cell-based therapy', and that 'new stem cell therapies would be subject to the same safety, efficacy and quality requirements as any other new medicine.' ${ }^{4}$ While this is correct from the perspective of a 'new medicine', the Medicines Act does not deal with many other matters pertaining to stem cells referred to above, most of which are covered by the recently promulgated sections of chapter 8. Failure to recognise this diversity reflects a lack of understanding of the complexity of cell biology in general, and stem cell biology in particular. The most vulnerable people are frequently targeted in settings in which untested and costly so-called stem cell treatments are utilised, and consequently need to be protected. ${ }^{11}$ It is likely that the Consumer Protection Act, in which the strict liability principle places the responsibility on any identifiable component/ person in the supply chain, will play an important role in protecting vulnerable patients. ${ }^{12}$

\section{Enactment of chapter 8 of the NHA and regulations thereto}

All the sections of chapter 8 of the NHA have now been enacted and the HTA has been repealed. Thus, section 53 of the NHA came into force on 30 June $2008^{13}$ and sections 55, 56 and 68 on 17 May 2011, ${ }^{14}$ the remaining sections 54 and $57-67$ being enacted on 1 March $2012 .{ }^{15}$ In addition, several sets of regulations that are pertinent to chapter 8 were published on 2 March 2012. ${ }^{16}$

While the promulgation of chapter 8 and regulations thereto might be a welcome step towards partial relief from the regulatory vacuum, several important gaps still exist and several newly introduced inaccuracies have added further complexity to the situation. A few examples follow.

Although the definition of 'stem cells' as 'cells that have both the capacity to self-regenerate as well as to differentiate into mature 
specialised cells' is accurate and consistent in three of the regulations published on 2 March 2012, ${ }^{17-19}$ different definitions are given for 'cell' in two of the regulations published on the same date. Thus, while the definition of a cell as 'the smallest structural and functional unit of an organism, consisting of cytoplasm and a nucleus enclosed in a membrane in living things ${ }^{17}$ is scientifically more accurate, it would be important to determine how the definition of a cell as 'a small container of chemical and water wrapped in a membrane ${ }^{20}$ would hold up under legal scrutiny.

In the recently promulgated section 57 of chapter 8 , 'Prohibition of reproductive cloning of human beings', therapeutic cloning is defined as 'the manipulation of genetic material from either adult, zygotic or embryonic cells in order to alter, for therapeutic purposes, the function of cells or tissues. ${ }^{21}$ The universally accepted definition of therapeutic cloning is 'somatic cell nuclear transfer', which could conceivably be embraced by the definition currently in chapter 8 . However, the definition of therapeutic cloning in section 57 is far broader than somatic cell nuclear transfer, and ironically is closer in part to the definition of the procedure required to produce genetically modified and transgenic cells or organisms.

The definition of transgenic cells is given as 'cells derived from a species other than human. ${ }^{17}$ This is incorrect. The accepted definition of cells derived from other species is xenogeneic. This fundamental error could have important consequences, particularly in South Africa where there is currently a rapid escalation in litigation for medical malpractice. ${ }^{22}$

Much effort will now be required to correct these inadequacies, which involve the Act (chapter 8) and many of the regulations.
Revision of the regulations is less onerous, as it requires the approval of the Minister of Health. Revision of the Act is more complex, and will require a passage through Cabinet and Parliament. Chapter 8 will apparently only be revised with revision of the entire Act, which may take some time. In the meantime we must live and work with the legislation at hand, and where this is lacking or inaccurate, be guided by international best practice.

1. Editorial. In the rear and limping a little? BMJ 1986;292:1028

2. National Health Act No. 61 of 2003 .

3. Human Tissue Act No. 65 of 1983

4. Jordaan D. Regulatory crackdown on stem cell therapy: What would the position be in South Africa? S Afr Med J 2012;102:226-228.

5. Medicines and Related Substances Control Act No. 101 of 1965.

6. Children's Act No. 38 of 2005

7. Inquest Act No. 58 of 1959.

8. Consumer Protection Act No. 68 of 2008

9. Pepper MS. Enactment of Chapter 8 of the National Health Act and regulations thereto. South African Journal of Bioethics and Law 2012;5(1):60.

10. Pepper M.S. The stem cell regulatory environment in South Africa: cause for concern. S Afr Med J 2009;99:505-507.

1. Pepper MS. Cell-based therapies: navigating troubled waters. S Afr Med J 2010;100:34-35.

12. Slabbert MN, Pepper MS. No-fault liability of health care providers in terms of the Consumer Protection Act. S Afr Med J 2011;101:800-801.

13. Proclamation No. 22 in Government Gazette No. 31187 of 27 June 2008

13. Proclamation No. 22 in Government Gazette No. 31187 of 27 June 2008 .

14. Proclamation No. 20 in Government Gazette No. 33187 of 14 May 2010.

16. Government Notices R175-R183 in Government Gazette No. 35099 of 2 March 2012.

17. Regulations relating to the Use of Human Biological Material in Government Notice R177 of Government Gazette No. 35099 of 2 March 2012.

8. Regulations relating to Blood and Blood products in Government Notice R179 of Government Gazette No. 35099 of 2 March 2012.

9. Regulations relating to Stem Cell Banks in Government Notice R183 of Government Gazette No. 35099 of 2 March 2012

20. Regulations relating to Artificial Fertilization of Persons in Government Notice R175 of Government Gazette No. 35099 of 2 March 2012.

1. Section 57(6)(b) of the National Health Act No. 61 of 2003.

22. Pepper MS, Slabbert MN. Is South Africa on the verge of a medical malpractice litigation storm? South African Journal of Bioethics and Law 2011;4(1):29-35. 